\title{
Perturbations at the ribosomal genes loci are at the centre of cellular dysfunction and human disease
}

\author{
Jeannine Diesch ${ }^{1,2}$, Ross D Hannan ${ }^{1,2,3,4,5,6}$ and Elaine Sanij ${ }^{1,2,7^{*}}$
}

\begin{abstract}
Ribosomal RNA (rRNA) gene (rDNA) transcription by RNA Polymerase I (Pol I) drives cell growth and underlies nucleolar structure and function, indirectly coordinating many fundamental cellular processes. The importance of keeping rDNA transcription under tight control is reflected by the fact that deranged Pol I transcription is a feature of cancer and other human disorders. In this review, we discuss multiple aspects of rDNA function including the relationship between Pol I transcription and proliferative capacity, the role of Pol I transcription in mediating nucleolar structure and integrity, and rDNA/nucleolar interactions with the genome and their influence on heterochromatin and global genome stability. Furthermore, we discuss how perturbations in the structure of the rDNA loci might contribute to human disease, in some cases independent of effects on ribosome biogenesis.
\end{abstract}

Keywords: rDNA, RNA Polymerase I, Nucleoli, UBF

\section{Introduction to rDNA transcription by Pol I}

In human cells 300 copies of the rRNA genes are arranged in repeated arrays located in nucleolar organizer regions (NORs) on the short arms of the acrocentric chromosomes [1-5]. Pol I transcribes rDNA to produce the $47 \mathrm{~S}$ rRNA, which is the precursor of the mature $28 \mathrm{~S}, 5.8 \mathrm{~S}$, and $18 \mathrm{~S}$ rRNAs. Together with the $5 \mathrm{~S}$ rRNA transcribed by Pol III in the nucleoplasm, these rRNAs form the nucleic acid backbone of the ribosome. The other major components of the ribosome are the $\sim 78$ ribosomal proteins (RPs), whose genes are transcribed by Pol II, and are assembled with the rRNAs to form functional ribosomes [6]. In growing mammalian cells, rRNA synthesis by Pol I accounts for $35-60 \%$ of all nuclear transcription while rRNA represents nearly $80 \%$ of the steady-state cellular RNA content $[7,8]$. Accordingly, Pol I transcription rate is tightly coupled to cellular growth and proliferation rates, and is modulated in response to a multitude of cellular cues including nutrient availability, growth factor signaling, cell cycle progression, differentiation, senescence, and

\footnotetext{
*Correspondence: elaine.sanij@petermac.org

'Growth Control Laboratory, Research Division, Peter MacCallum Cancer

Centre, St. Andrews Place, East Melbourne, Victoria 3002, Australia

${ }^{2}$ Sir Peter MacCallum Department of Oncology, University of Melbourne,

Parkville, Victoria 3010, Australia

Full list of author information is available at the end of the article
}

DNA damage [8-13]. Inhibition of Pol I transcription leads to cell cycle arrest associated with apoptosis, senescence or autophagy depending on the cell type [14-17]. Hence, rDNA transcription has been proposed to directly couple cell growth to cell cycle progression and to influence the decision of a cell to arrest in response to various forms of stress $[18,19]$. Not surprisingly, it is becoming increasingly clear that dysregulation of Pol I transcription is linked to the aetiology of a broad range of human diseases [20].

rDNA transcription underpins the structure of the nucleoli, which form around active clusters of rDNA [21]. However, the primary function of the nucleoli is not limited to the production of the ribosomal subunits [22-25]. Bioinformatic analysis of the nucleolar proteome revealed that only $30 \%$ of the nucleolar proteins are involved in ribosome biogenesis, while included in the rest are factors associated with mRNA metabolism, chromatin structure, cell cycle control, DNA replication and repair [21,22,26-31]. The nucleolus indirectly, through sequestration and release of these proteins, has the ability to modulate a diverse range of cellular functions including regulating tumor suppressor and proto-oncogene activities, cell-cycle control, DNA replication and repair, and stress signaling independent of ribosome biogenesis [23,25,26,32-41]. Perturbation of nucleolar structure and function leads to a 
response termed "nucleolar stress", characterized by the accumulation of the tumour suppressor protein p53 leading to induction of apoptosis, senescence or cell cycle arrest $[18,23,42-50]$. Therefore, the nucleolus is at the centre of coordinating rDNA transcription, ribosome subunit biogenesis, cell cycle progression and cellular stress responses $[17,40,45,48]$.

Recent evidence also suggests that the epigenetic status of the rDNA repeats and the integrity of the nucleolus can modulate cellular homeostasis beyond ribosome biogenesis and nucleolar stress. Spatial organization of the genome around the nucleoli and the interactions of specific chromatin domains with the nucleoli are both suggested to affect the various functions of the nucleoli and vice versa $[51,52]$. Furthermore, the repetitive nature and high transcription rates of the rRNA genes render the rDNA some of the most fragile sites in the genome [53]. Somewhat surprisingly, only a fraction of the rRNA genes is transcriptionally active at any given time. In yeast, the silent rDNA copies appear to play an essential role in maintaining the genetic stability of the rDNA repeats [54]. Epigenetic silencing of rDNA has also been proposed to mediate nucleolar integrity, genomic stability, and the global regulation of gene expression [52,55], with these having downstream effects on cellular processes such as senescence and aging [11,56-58].

This review provides an overview of the mechanisms that regulate rDNA transcription. We will discuss the spatial organization of the nucleoli around actively transcribed rDNA and their potential functional interactions with the rest of the genome, and the notion of rDNA instability promoting genome-wide instability and influencing cellular functions such as, maintainance of heterochromatin, DNA damage response and aging. Further, we present our current knowledge of human diseases specifically associated with deregulated Pol I transcription.

\section{Regulation of Pol I transcription}

In addition to RNA Polymerase I, optimal rRNA gene transcription requires a number of accessory factors that facilitate Pol I recruitment, initiation, promoter escape, elongation, termination and re-initiation [12,59,60]. Pol I transcription begins with the formation of the preinitiation complex (PIC) by the upstream binding factor (UBF) and the TBP-containing complex selectively factor (SL-1, also called TIF-1B) at the rDNA promoter. SL-1 confers promoter sequence specificity by recognizing the core promoter element and it promotes a stable interaction between UBF and the rDNA promoter [61-64]. In turn, UBF binds the upstream and core promoter elements (UCE and CORE) as a dimer, possibly looping the intervening DNA into a nucleosome like structure termed the enhancesome, which brings the activating UCE sequence into close proximity with the core promoter element [65-67].
UBF binding also promotes stabilization of SL-1 interaction with the rDNA promoter [68]. The resultant UBF/ SL-1 complex then facilitates recruitment of an initiationcompetent subpopulation of Pol I, defined by the presence of the basal regulatory factor RRN3 (also called TIF-1A), to form a productive $\mathrm{PIC}$ at the rDNA promoters [8,68-72]. Furthermore, UBF interacts with the entire transcribed region [73-75], not just promoter elements, and can regulate promoter escape [76] and Pol I elongation in response to growth stimuli [77].

Despite the high demand for rRNA synthesis, only a subset of rRNA genes is transcribed at any given time. In mammalian cells, rDNA chromatin can exist in at least four distinct states $[78,79]$. The first two states are defined as open/accessible chromatin structures. They are bound by UBF, which is essential in determining and maintaining the active rDNA state [80], and are characterized by being transcriptionally active and transcriptionally poised states. RNA interference-mediated depletion of UBF silences active rRNA genes by promoting histone $\mathrm{H} 1$-induced assembly of closed transcriptionally inactive chromatin [80]. The two states of inactive rDNA chromatin represent silenced rDNA that is devoid of UBF and Pol I and are distinguished by the presence or absence of methylated $\mathrm{CpG}$ dinucleotides in the rDNA promoter. The silenced nonmethylated fraction is thought to carry activating histone marks that can presumably transit to the open chromatin state if rDNA becomes bound by UBF. In contrast, the methylated rDNA population is believed to carry repressive histone marks and is established and stably maintained by the nucleolar repressive complex NoRC, a member of the ATP-dependent chromatin remodeling complexes [81-83]. Studies in yeast suggest that these silenced rRNA genes are required for efficient DNA recombination repair and thus play an important role in maintaining rDNA stability [56].

\section{Organization of the nucleoli}

The nucleolus is the subnuclear site of ribosome biogenesis and its formation around active NORs requires ongoing rDNA transcription. The structure of nucleoli is highly dynamic and is tightly coordinated with cell cycle progression. Nucleoli disassemble at the onset of mitosis coinciding with inactivation of Pol I transcription and reassemble during telophase as rDNA transcription is reinitiated. The rate of rRNA gene transcription reaches a maximum in $\mathrm{S}$ - and $\mathrm{G} 2$ phases, is halted at the onset of mitosis and slowly reactivated as cell enter G1 [84]. Cell cycle mediated regulation of rDNA transcription is facilitated by post-translational modifications of components of the Pol I transcription machinery and its associated transcription factors such as phosphorylation of UBF and SL-1 [85-87]. Interestingly, few components of the Pol I machinery, including Pol I as well as UBF and 
SL-1 remain associated with active NORs throughout mitosis, presumably to allow reactivation of Pol I transcription upon entry into the G1 phase [88-91]. Formation of nucleoli requires association of UBF with the rDNA, which acts as a scaffold to initiate and maintain nucleolar competency even in absence of rDNA transcription [91-93].

Once established, the nucleolus comprises three major structural and functional subcompartments defined by their texture and contrast using electron microscopy, the fibrillar centre (FC), the dense fibrillar component (DFC) and the granular component (GC) $[21,24,94,95]$. The FCs, in which the NORs can be found, are clear areas surrounded by highly contrasted DFCs. Depending on the rate of ribosome biogenesis one nucleolus can consist of several FCs whilst exponentially growing cells can exhibit several large nucleoli [96]. The majority of the $47 \mathrm{~S}$ precursor rRNA is thought to be synthesized at the boundary between the FC and the DFC [97]. DFCs harbour the small nucleolar ribonucleoproteins (RNPs) necessary for the first steps of rRNA processing, whereas the late steps of rRNA processing and assembly of the small (40S) and large (60S) ribosome subunits take place in the GCs [21,24].

The organization, size and protein composition of the nucleoli change dramatically during the cell cycle and under different cellular conditions, including stress and viral infections $[39,40,48,98-102]$. Over 4500 proteins reside within human nucleoli and through the control of their sequestration and release, nucleoli modulate a diverse range of cellular functions such as control of the cell-cycle apparatus, ageing, cellular stress responses, mRNA export and modification, protein degradation, assembly and export of RNPs [21-28,31,33,45,48,103-105]. One such sequestration function involves non-coding RNA produced from the intergenic spacer (IGS), which separates the rDNA repeats. This noncoding RNA is produced in response to various stimuli including acidosis, heat shock and transcriptional stress and is capable of capturing and immobilizing key cellular proteins that encode a discrete peptidic code referred to as the nucleolar detention sequence (NoDS) [32]. Disruption of the NoDS/intergenic RNA interaction enables proteins to escape nucleolar sequestration and retain their nucleoplasmic function $[32,106]$. NoDS-carrying proteins are involved in diverse functions including ubiquitination, proteasomal degradation, protein folding, DNA replication and methylation [107]. Nucleolar retention of proteins away from their normal sites of action is a further example of the multifunctional nature of the nucleoli $[33,45,48,108]$.

\section{Nucleolar coordination of cellular stress response}

Nucleolar integrity is tightly linked to rRNA gene transcription and ribosome biogenesis. Downregulation of
Pol I transcription seems to be a major strategy to maintain cellular homeostasis under adverse growth conditions or metabolic deficits [83,87,109-113]. Furthermore, a variety of abnormal metabolic conditions, cytotoxic agents, and physical insults induce alterations in nucleolar structure and function, and ribosome biogenesis $[48,110,114]$. The rate of ribosome biogenesis is now thought to function as a highly sensitive cellular sensor of stress.

Virtually any major cellular perturbation that uncouples the processes driving ribosome synthesis and assembly results in the activation of a regulated series of events that are controlled through the nucleoli, which activate cell cycle checkpoints leading to cell cycle arrest or cell death [18,44,46-48,115-117]. This process has been termed nucleolar stress or ribosome surveillance. One of most prominent events downstream of nucleolar stress is activation of the p53 tumour suppressor protein, a key regulator of stress-induced apoptosis, DNA repair, cell cycle arrest, and senescence [18,22,42-44,46,48,50,118,119]. In this pathway p53 is activated by the essential $60 \mathrm{~S}$ ribosomal proteins RPL11 and RPL5 that function in a MDM2 inhibitory complex with $5 \mathrm{~S}$ rRNA, which binds MDM2 and blocks its function to degrade p53 [120-129]. Thus, a dynamic equilibrium exists in the cell, which couples ongoing ribosome biogenesis to p53 protein stability, such that the RPL5/RPL11/5S rRNA complex is either incorporated into nascent ribosomes or is bound to MDM2. Therefore, this is a key pathway that enables the coordination of ribosome production with cell proliferation [120]. We and others have also identified p53 independent checkpoints that are activated in response to inactivation of Pol I transcription, although the mechanism controlling this process is not understood (Quin J. and Sanij E. unpublished data), [130,131]. Taken together, the direct coupling of Pol I transcription and the ribosome biogenesis rate through the nucleolar stress pathway ensures a coordinated response to a variety of proliferative and stress stimuli.

\section{Genome organization around the nucleoli}

The structure of the genome is highly dynamic and is closely coupled with gene regulation. It is now well accepted that the nucleus is organized into chromosome territories and transcription factories in which functionally related genes cluster together allowing their concerted regulation [132]. Furthermore, the spatial organization and location of chromosomes and their interactions with other nuclear substructures ensures that transcription is correctly regulated and maintains genome stability $[133,134]$. The discovery of structural and functional links between the nucleolus and the rest of the genome have led to the proposal that the nucleolus plays a key role in mediating nuclear architecture [135]. 
The periphery of the nucleolus contains satellite DNA repeats, which are thought to be involved in the formation of perinucleolar heterochromatic domains surrounding the nucleolus as a dense shell [136]. CpG-methylated silent rDNA assembles in proximity to the perinucleolar heterochromatin, suggesting a specific relationship between these heterochromatic regions and silent rDNA copies [137]. Indeed, NoRC mediated silencing of rDNA is important for the formation of the perinucleolar domains [57]. Regions found in the perinucleolar region, termed nucleolar-associated domains (NADs), include centromeres of chromosome 1 and 9 and chromosome $Y$ heterochromatin [138]. Recent high-resolution genome-wide mapping of NADs revealed the association of nucleoli with various satellite repeats (mainly alpha-, beta- and $(\text { GAATG })_{n} /(\text { CATTC })_{n}$-types) and genes belonging to the zinc finger, olfactory receptor and immunoglobulin gene families [139]. In addition, the region flanking the rDNA on the telomeric side contains a large tract of a satellite repeat family that is specific to the acrocentric chromosomes [140]. Similar to lamina-associated domains (LADs), which are localized at the nuclear envelope, a strong correlation of NADs with AT-rich sequences and regions with low gene density has also been observed [141].

Genes enriched in the NADs are characterized by repressive histone marks and a lack of gene expression. Indeed, the NADs have been proposed to serve as a distinct nuclear space with a primary function in maintaining repressive chromatin states $[51,141]$. For example, the inactive $\mathrm{X}$-chromosome visits the nucleoli during S-phase to maintain its repressive state [142]. A repressive, inhibitory effect of the nucleoli on gene expression has also been demonstrated by inducing nucleolar association in response to random multicopy insertion of ectopic 5S rDNA sequences in ES cell lines, which resulted in transcriptional repression of genes adjacent to the insertion site [143]. Indeed, RNA genes transcribed by RNA polymerase III, such as $5 \mathrm{~S}$ rRNA, tRNA and U6 snRNA are also localized within NADs and are thought to recruit adjacent protein coding genes to the nucleoli $[144,145]$. As Pol III-transcribed genes and derived sequences make up a large proportion of the genome, it has been proposed that these can significantly contribute to nucleolar association of neighboring genes for the purpose of mediating gene silencing [143]. However, there is no enrichment of these elements in the regions immediately flanking the rDNA arrays even though they show perinucleolar localization [140]. Apart from Pol III-transcribed genes, several other factors have been suggested to tether chromatin regions to the nucleoli. One example is the CCCTC-binding factor (CTCF), which regulates various cellular processes and has recently been shown to affect nuclear structure by binding to insulator sequences, preventing crosstalk between neighboring sequences, and facilitating chromatin loops between CTCF binding elements [146]. CTCF has been shown to localize to the nucleoli where it interacts with nucleolar proteins such as nucleophosmin [147] and UBF [148]. A third class of potential nucleolus-tethering factors is long noncoding RNAs (lncRNAs). For instance, the lncRNAs Kcnq10t1 promotes the lineage-specific inhibition of genes in the Kcnq1 domain by inducing their relocation to the nucleoli $[149,150]$. A similar mechanism has been shown to be involved in the perinucleolar targeting of the inactive $\mathrm{X}$ chromosome mediated by the Xist RNA [142]. Further, unique lncRNAs are produced from the rDNA arrays flanking regions, although their function has not been determined [140].

Taken together, the observed enrichment of heterochromatic regions and transcriptionally repressed genes in perinucleolar domain suggests that the NADs represent a novel mechanism of gene silencing. However, more experiments need to be performed to completely rule out the possibility of nucleolar localization being a mere consequence of inactive gene expression. Additionally, the composition of NADs in disease and their biological relevance are not well understood.

\section{rDNA stability maintains genome integrity}

The repetitive nature of the rDNA leaves them vulnerable to loss or gain of rDNA copies through a high rate of recombination [151,152], although this remains poorly studied in humans [2]. Changes in the number of rDNA copies can create an imbalance in the ratio of silent to active repeats that affects global heterochromatin content [57]. This in turn can lead to deregulated gene expression, promoting genome instability [153]. Indeed, rDNA instability has been observed in Bloom syndrome patients, which harbour a mutation in the DNA helicase BLM gene leading to dysregulated homologous recombination (HR) [154]. rDNA instability can also be detected in cells deficient for ataxia-telangiectasia (ATM), the primary sensor of DNA double stranded breaks. In Bloom syndrome and ataxia-telangiectasia patients, rDNA instability correlates with increased cancer predisposition [154]. The rDNA is a recombinational hotspot in cancer, suggesting that rDNA instability may be a mechanism of global genomic instability and could drive the etiology and progression of cancer [53,155]. Neurodegeneration also appears to be associated with instability of rDNA [156], including Alzheimer's disease [157].

The importance of rDNA copy number and rDNA integrity is implied by the existence of a well-regulated maintenance system in yeast which keeps rDNA copy number at a uniform level, as well as the tight regulation of rDNA recombination [152]. During yeast HR, which is the major cause of rDNA copy variation [158-160], rDNA repeats that are being repaired are transported 
out of the nucleolus into nuclear repair foci, presumably to prevent rDNA hyper-recombination. This nucleolar exclusion is mediated by the Smc5-Smc6 complex and the sumoylation of the central HR protein Rad52 [161]. In addition, anti-recombinatoric regulators such as Srs2 are found in close proximity to the rDNA [161].

Several studies in yeast suggest a strong correlation between rDNA copy number and genome integrity [152,162]. In 2008, Kobayashi T. (National Institute of Genetics, Japan) introduced the "rDNA theory" of aging, in which rDNA instability-dependent aging is proposed to induce senescence and prevent global genome instability $[162,163]$. In Drosophila, general heterochromatin content appears to be directly influenced by the number of rDNA copies suggesting that rDNA instability may affect heterochromatin maintenance [58]. Consistent with this, induced rDNA deletions altered the expression of hundreds to thousands of euchromatic genes throughout the genome [55]. The relationship between rDNA and genome stability has also been demonstrated in mouse cells, where loss of rDNA silencing results in destabilization of the perinucleolar heterochromatin, which is crucial for ensuring genome stability $[57,83]$.

In addition to the role of rDNA in regulating heterochromatin, silent rDNA repeats are required for DNA damage repair, an essential pathway for preventing genome instability. The influence of rDNA on DNA damage has been shown utilizing yeast strains that have reduced rDNA copy numbers, in which most or all copies are actively transcribed $[56,164]$. These low-copy strains have impaired DNA damage repair during S-phase and consequently higher sensitivity to DNA damaging agents such as ultraviolet radiation and methyl methanesulfonate [56]. The sensitivity to DNA damage is due to the inability of condensin, which is required for sister-chromatid cohesion and facilitates DNA repair, to bind the active rDNA repeats [56]. A relationship between condensin and rDNA has been demonstrated in several other studies further supporting the idea that silent rDNA repeats are required for rDNA repair [165-168]. Moreover, studies in yeast led to the proposition that silent copies of rDNA can sequester mediators of the DNA damage repair pathway and that the rDNA acts as a stress centre for DNA damage $[56,158]$. Hence, variations in rDNA copy number may influence cellular responses to DNA damage (Figure 1).

In summary, rDNA repeats are crucial players in the maintenance of genome stability. Perturbations at the rDNA loci resulting in either a decrease or increase in rDNA copies have a great impact on cellular processes, including heterochromatin structure and function, global gene expression and DNA damage response. These processes can then, in turn, promote aging, cancer and disease (Figure 1).

\section{Deregulation of rDNA transcription in disease}

Upregulation of Pol I activity is common in diseases associated with profound changes in cellular growth, such as cardiac disease [169] and cancer [15-17,116,170,171]. Indeed, enlarged nucleoli indicative of increased Pol I transcriptional activity and ribosome biogenesis are associated with cardiac pathophysiology [169]. Similarly, the nucleoli of cancer cells are enlarged and increased in number, and thus the morphology of nucleoli is commonly used as a diagnostic marker for transformed cells clinically corresponding to adverse prognosis $[172,173]$. These data suggest it is incorrect to consider rDNA transcription as simply a "house keeping" process that reflects the metabolic state of somatic cells. Indeed, recent findings demonstrate that deregulation of Pol I transcription is necessary for malignant transformation in certain systems [174].

Pol I activity is frequently deregulated in cancers by oncogene activation and/or tumor suppressor inactivation $[17,18,20]$ and this has been previously explained in terms of an increased demand for ribosomes in highly proliferative cells. Certain tumour cells however appear to be very susceptible to inhibition of Pol I transcription leading to induction of cancer cell death $[14,174,175]$. This therapeutic benefit is due to tumour-specific induction of the nucleolar stress pathway leading to activation of p53 and cell death by apoptosis. Activation of the p53 pathway following inhibition of Pol I transcription in tumour cells is not a consequence of ribosome insufficiency, suggesting that the cells are responding directly to perturbations in rDNA transcription [174]. The therapeutic efficacy of targeting deregulated Pol I activity in cancer is currently being investigated using a selective small molecule inhibitor of Pol I transcription, CX-5461 $[14,174]$, that is in phase 1 clinical trials (Peter MacCallum Cancer Centre, Melbourne, Australia) as a mechanism to selectively and non genotoxically activate the p53 pathway in cancer cells.

Further, deregulation of rDNA transcription contributes to the pathology of several rare human genetic disorders (reviewed in [20]). These conditions are caused by loss of function mutations in factors directly associated with Pol I transcription, modulators that impact on Pol I transcription, or mutations that affect rRNA processing or rRNA modifications. These diseases, as well as those associated with loss of function mutations in the molecular constituents of the ribosome, are termed ribosomopathies (reviewed in $[20,176]$ ). To date at least six human syndromes (Treacher Collins syndrome, Blooms and Werner syndrome, Cockayne Syndrome, Siderius X-linked mental retardation, and a group of Filamin A associated diseases) are associated with mutations in genes whose products interact directly with rDNA or the Pol I transcriptional complex. Generally, 


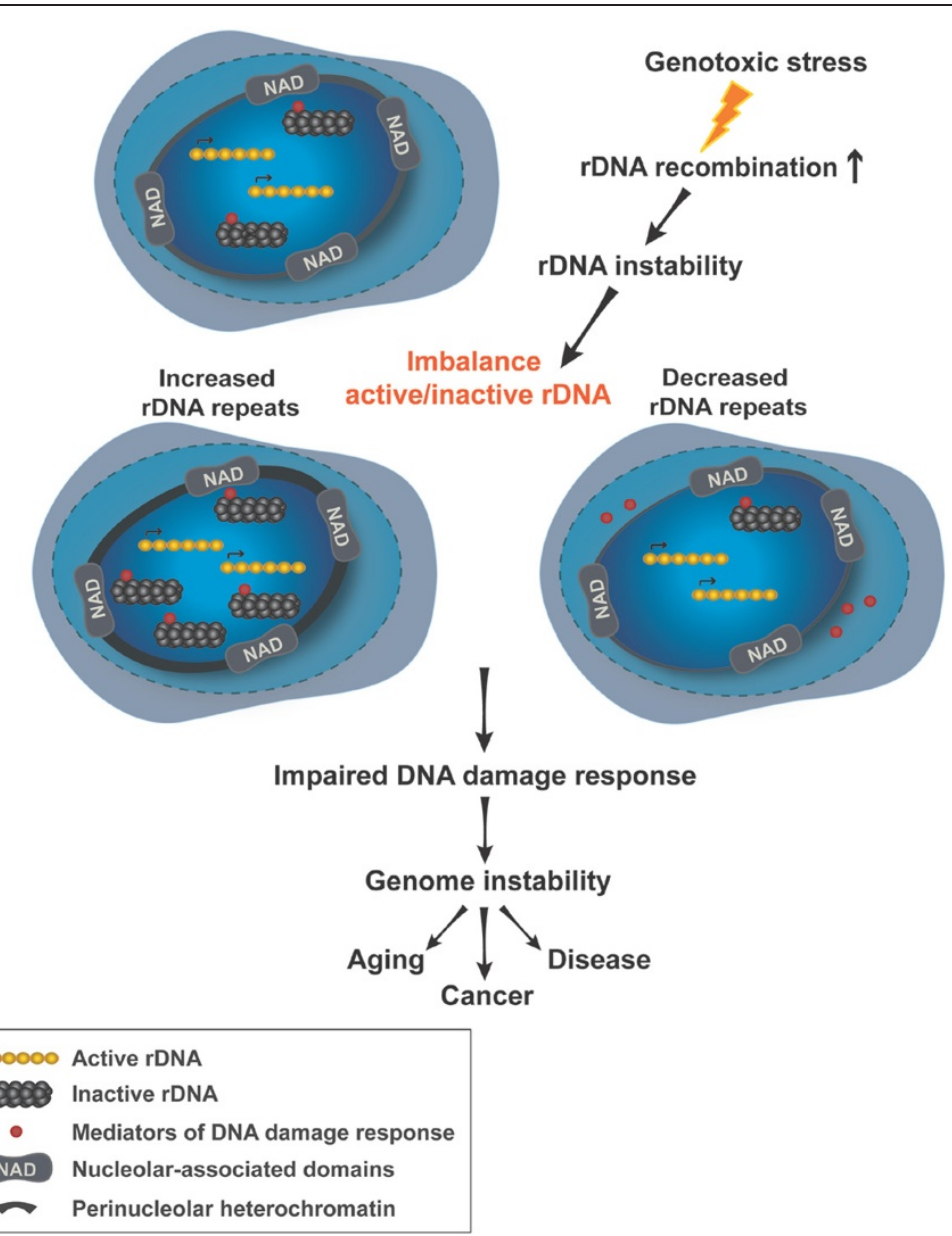

Figure 1 Proposed model of genome-wide consequences of rDNA instability. Under normal conditions rDNA copy number is maintained at uniform levels due to tight control of homologous recombination (HR) at rDNA loci. Induced HR in response to DNA damaging stimuli can lead to an increase or decrease in rDNA copy number resulting in an imbalance in the ratio of active to silent rDNA. This, in turn, will affect ribosome biogenesis independent functions of rDNA, which include regulation of heterochromatin content and DNA damage response leading to global genome instability and promoting aging or disease.

these mutations are associated with reduced rRNA synthesis and nucleolar malfunction [20].

Cohesinopathies are another group of human congenital disorders associated with deregulated Pol I transcription. Cornelia de Lange and Roberts Syndrome are associated with mutations in genes encoding either regulators or structural components of the cohesin complex, which is critical for sister chromatid cohesion, chromosome segregation during $\mathrm{S}$ phase, chromosome condensation, DNA damage repair and gene regulation including Pol I transcription of the rRNA $[18,177,178]$. Although the cohesin complex has been reported to interact with rDNA [178], the molecular mechanisms that lead to deregulation of Pol I transcription in these diseases have not been established. While ribosomopathies and cohesinopathies are unique, collectively they exhibit overlapping symptoms including craniofacial abnormalities and growth retardation.
Downregulation of rDNA transcription has been proposed to determine cell fate and to act as a trigger for cellular differentiation $[179,180]$. Thus, it is plausible that deregulation of Pol I transcription is the underlying cause of these common features [20].

Downregulation of rRNA synthesis and nucleolar size has also been observed during aging $[181,182]$. Altered rRNA gene transcription and disruption of nucleolar integrity and function are associated with the pathogenesis of age-related neurological disorders such as Alzheimer's disease [157], Huntington's diseases [183,184], Parkinson disease [185] and spinocerebellar ataxias [186]. More recently, elevated rDNA copy number was detected in patients with dementia with Lewy bodies, which involves neurodegeneration of the cerebral cortex [156]. Moreover, increased genomic content of the $18 \mathrm{~S}$ rDNA region and an increase in rDNA silencing, distinguished by 
rDNA promoter methylation has been detected in the parietal cortex of Alzheimer's disease patients [157].

The evolving paradigm of the nucleolus being a key regulator of cellular homeostasis implicates nucleolar stress resulting from deregulation of rDNA transcription in the development of these diseases. Unquestionably, further mechanistic investigations are required in order to examine how perturbations of rDNA stability and function, independent of ribosome biogenesis and nucleolar stress, are involved in the aetiology of these diseases.

\section{Conclusions}

Taken together, this review advocates a role for the nucleoli in genome organization and the regulation of gene expression beyond its classic role in ribosome biogenesis and nucleolar stress response. Variation in rDNA copy number alters the ratio of active to silent rDNA repeats, which in turn can alter heterochromatin content. As such, changes at rDNA loci could affect gene expression and alter global genomic stability driving an imbalance in cellular homeostasis leading to disease. Analysis of rDNA/nucleolus interactions with chromatin domains concomitant with genome-wide gene expression analyses under various cellular conditions are the next steps necessary to understand $\mathrm{rDNA} /$ nucleolar functions at genome-wide as well as system levels.

\section{Abbreviations \\ ATM: CCTF, CCCTC-binding factor; DFC: Dense fibrillar component; FC: Fibrillar centre; GC: Granular component; HR: Homologous recombination; IGS: Intergenic spacer; LADs: Lamina associated domains; IncRNA: Long noncoding RNA; NADs: Nucleolar associated domains; NOR: Nucleolar organizer region; NoRC: Nucleolar repressive complex; NoDS: Nucleolar detention sequence; PIC: Preinitiation complex; Pol: RNA polymerase I; rDNA: Ribosomal gene; RNPs: Ribonucleoproteins; RP: Ribosomal proteins; rRNA: Ribosomal RNA; SL-I: Selectivity factor 1; UBF: Upstream binding factor.}

\section{Competing interests}

The authors declare that they have no competing interests.

\section{Authors' contributions}

JD and ES contributed equally to writing this review. RDH provided substantive intellectual input. All authors read and approved the final manuscript.

\footnotetext{
Authors' information

ES received her PhD from Monash University (Melbourne, Australia) in 2003 and was awarded a Cancer Research UK Postdoctoral Fellowship to undertake research in Dr. Gordon Peters laboratory at the London Research Institute (London, United Kingdom). Since 2006, she worked as a Senior Research Scientist in the Growth Control Laboratory at the Peter MacCallum Cancer Institute (Melbourne, Australia). Her studies examine epigenetic regulation of ribosomal gene (rDNA) transcription (Sanij et al., JCB 2008) with a focus on the use of next generation sequencing to characterize the chromatin state of the rDNA. Further, she made seminal contributions in identifying deregulation of Pol I transcription as a requirement for malignant transformation and the therapeutic efficacy of targeting Pol I transcription in cancer (Drygin et al., Cancer Res 2011; Bywater et al., Cancer Cell 2012; Hein et al., Trends Mol Med 2013).
}

\section{Acknowledgments}

We thank Dr. Austen Ganley (Massey University, New Zealand), Dr. Gretchen Poortinga (Peter MacCallum Cancer Centre, Australia) and Ms Jaclyn Quin (Peter MacCallum Cancer Centre, Australia) for critical evaluation of the manuscript. This work was supported by Grants from the National Health and Medical Research Council of Australia (NHMRC). RDH is supported by a NHMRC Fellowship.

\section{Disclosure declaration}

The authors are not aware of any biases that might affect the objectivity of this review.

\section{Author details}

${ }^{1}$ Growth Control Laboratory, Research Division, Peter MacCallum Cancer Centre, St. Andrews Place, East Melbourne, Victoria 3002, Australia. ${ }^{2}$ Sir Peter MacCallum Department of Oncology, University of Melbourne, Parkville, Victoria 3010, Australia. ${ }^{3}$ Department of Biochemistry and Molecular Biology, Monash University, Clayton, Victoria 3800, Australia. ${ }^{4}$ Department of Biochemistry and Molecular Biology, University of Melbourne, Parkville, Victoria 3010, Australia. ${ }^{5}$ Division of Cancer Medicine, Peter MacCallum Cancer Centre, St. Andrews Place, East Melbourne, Victoria 3002, Australia. ${ }^{6}$ School of Biomedical Sciences, University of Queensland, Brisbane, Queensland 4072, Australia. ${ }^{7}$ Department of Pathology, University of Melbourne, Parkville, Victoria 3010, Australia.

Received: 15 June 2014 Accepted: 27 July 2014

Published: 19 August 2014

\section{References}

1. McConkey EH, Hopkins JW: The Relationship of the Nucleolus to the Synthesis of Ribosomal Rna in Hela Cells. Proc Natl Acad Sci U S A 1964, 51:1197-1204.

2. Stults DM, Killen MW, Pierce HH, Pierce AJ: Genomic architecture and inheritance of human ribosomal RNA gene clusters. Genome Res 2008, 18:13-18.

3. Henderson AS, Warburton D, Atwood KC: Location of ribosomal DNA in the human chromosome complement. Proc Natl Acad Sci U S A 1972, 69:3394-3398.

4. Jeanteur P, Attardi G: Relationship between HeLa cell ribosomal RNA and its precursors studied by high resolution RNA-DNA hybridization. $J \mathrm{Mol}$ Biol 1969, 45:305-324.

5. Schmickel RD: Quantitation of human ribosomal DNA: hybridization of human DNA with ribosomal RNA for quantitation and fractionation. Pediatr Res 1973, 7:5-12.

6. Leary DJ, Huang S: Regulation of ribosome biogenesis within the nucleolus. FEBS Lett 2001, 509:145-150.

7. Cavanaugh AHH-L, Rothblum Ll: Ribosomal DNA Transcription in Mammals. In The Nucleolus. Edited by Olson MOJ. (Landes, Austin, TX): Kluwer Academic/ Plenum Publishers; 2004.

8. Moss T, Stefanovsky W: At the center of eukaryotic life. Cell 2002, 109:545-548.

9. Chan JC, Hannan KM, Riddell K, Ng PY, Peck A, Lee RS, Hung S, Astle MV, Bywater M, Wall M, Poortinga G, Jastrzebski K, Sheppard KE, Hemmings BA, Hall MN, Johnstone RW, McArthur GA, Hannan RD, Pearson RB: AKT promotes rRNA synthesis and cooperates with C-MYC to stimulate ribosome biogenesis in cancer. Sci Signal 2011, 4:ra56.

10. Hannan RD, Rothblum LI: Regulation of ribosomal DNA transcription during neonatal cardiomyocyte hypertrophy. Cardiovasc Res 1995, 30:501-510.

11. Hein N, Sanij E, Quin J, Hannan KM, Ganley ARD, Hannan RD: The Nucleolus and Ribosomal Genes in Aging and Senescence. In Senescence. Edited by Nagata T. InTech; 2012. ISBN: 978-953-51-0144-4, InTech, doi:10.5772/34581. Available from: http://www.intechopen.com/books/senescence/the-nucleolusin-aging-and-senescence-

12. McStay B, Grummt I: The epigenetics of rRNA genes: from molecular to chromosome biology. Annu Rev Cell Dev Biol 2008, 24:131-157.

13. Russell J, Zomerdijk JC: The RNA polymerase I transcription machinery. Biochem Soc Symp 2006, 73:203-216.

14. Drygin D, Lin A, Bliesath J, Ho CB, O'Brien SE, Proffitt C, Omori M, Haddach M, Schwaebe MK, Siddiqui-Jain A, Streiner N, Quin JE, Sanij E, Bywater MJ, Hannan RD, Ryckman D, Anderes K, Rice WG: Targeting RNA polymerase I 
with an oral small molecule CX-5461 inhibits ribosomal RNA synthesis and solid tumor growth. Cancer Res 2011, 71:1418-1430.

15. Drygin D, O'Brien SE, Hannan RD, McArthur GA, Von Hoff DD: Targeting the nucleolus for cancer-specific activation of p53. Drug Discov Today 2014, 19:259-265

16. Drygin D, Rice WG, Grummt I: The RNA polymerase I transcription machinery: an emerging target for the treatment of cancer. Annu Rev Pharmacol Toxicol 2010, 50:131-156.

17. Quin JE, Devlin JR, Cameron D, Hannan KM, Pearson RB, Hannan RD: Targeting the nucleolus for cancer intervention. Biochim Biophys Acta 1842, 2014:802-816.

18. Hein N, Hannan KM, George AJ, Sanij E, Hannan RD: The nucleolus: an emerging target for cancer therapy. Trends Mol Med 2013, 19:643-654.

19. Russell J, Zomerdijk JC: RNA-polymerase---directed rDNA transcription, life and works. Trends Biochem Sci 2005, 30:87-96.

20. Hannan KM, Sanij E, Rothblum LI, Hannan RD, Pearson RB: Dysregulation of RNA polymerase I transcription during disease. Biochim Biophys Acta 1829, 2013:342-360

21. Pederson T: The nucleolus. Cold Spring Harb Perspect Biol 2011, 3:a000638. doi:10.1101/cshperspect.a000638.

22. Boisvert FM, van Koningsbruggen S, Navascues J, Lamond Al: The multifunctional nucleolus. Nat Rev Mol Cell Biol 2007, 8:574-585.

23. Pederson T, Tsai RY: In search of nonribosomal nucleolar protein function and regulation. J Cell Biol 2009, 184:771-776.

24. Sirri V, Urcuqui-Inchima S, Roussel P, Hernandez-Verdun D: Nucleolus: the fascinating nuclear body. Histochem Cell Biol 2008, 129:13-31.

25. Pederson T: The plurifunctional nucleolus. Nucleic Acids Res 1998, 26:3871-3876.

26. Andersen JS, Lam YW, Leung AKL, Ong SE, Lyon CE, Lamond Al, Mann M: Nucleolar proteome dynamics. Nature 2005, 433:77-83.

27. Andersen JS, Lyon CE, Fox AH, Leung AKL, Lam YW, Steen H, Mann M, Lamond Al: Directed proteomic analysis of the human nucleolus. Curr Biol 2002, 12:1-11.

28. Scherl A, Coute Y, Deon C, Calle A, Kindbeiter K, Sanchez J-C, Greco A, Hochstrasser D, Diaz J-J: Functional Proteomic Analysis of Human Nucleolus. Mol Biol Cell 2002, 13:4100-4109

29. Leung AKL, Trinkle-Mulcahy L, Lam YW, Andersen JS, Mann M, Lamond Al: NOPdb: nucleolar proteome database. Nucleic Acids Res 2006, 34:D218-D220.

30. Couté Y, Burgess JA, Diaz J-J, Chichester C, Lisacek F, Greco A, Sanchez J-C: Deciphering the human nucleolar proteome. Mass Spectrom Rev 2006, 25:215-234.

31. Ahmad Y, Boisvert FM, Gregor P, Cobley A, Lamond Al: NOPdb: Nucleolar Proteome Database-2008 update. Nucleic Acids Res 2009, 37:D181-D184.

32. Audas TE, Jacob MD, Lee S: Immobilization of proteins in the nucleolus by ribosomal intergenic spacer noncoding RNA. Mol Cell 2012, 45:147-157.

33. Olson MO, Dundr M: The moving parts of the nucleolus. Histochem Cell Biol 2005, 123:203-216.

34. Peddibhotla S, Wei Z, Papineni R, Lam MH, Rosen JM, Zhang P: The DNA damage effector Chk1 kinase regulates Cdc14B nucleolar shuttling during cell cycle progression. Cell Cycle 2011, 10:671-679.

35. Sasaki M, Kawahara K, Nishio M, Mimori K, Kogo R, Hamada K, Itoh B, Wang J, Komatsu Y, Yang YR, Hikasa H, Horie Y, Yamashita T, Kamijo T, Zhang Y, Zhu Y, Prives C, Nakano T, Mak TW, Sasaki T, Maehama T, Mori M, Suzuki A: Regulation of the MDM2-P53 pathway and tumor growth by PICT1 via nucleolar RPL11. Nat Med 2011, 17:944-951.

36. Bhaskaran N, van Drogen F, Ng HF, Kumar R, Ekholm-Reed S, Peter M, Sangfelt O, Reed SI: Fbw7alpha and Fbw7gamma collaborate to shuttle cyclin E1 into the nucleolus for multiubiquitylation. Mol Cell Biol 2013, 33:85-97.

37. Daniely Y, Dimitrova DD, Borowiec JA: Stress-dependent nucleolin mobilization mediated by p53-nucleolin complex formation. Mol Cell Biol 2002, 22:6014-6022.

38. Rancourt A, Satoh MS: Delocalization of nucleolar poly(ADP-ribose) polymerase-1 to the nucleoplasm and its novel link to cellular sensitivity to DNA damage. DNA Repair 2009, 8:286-297.

39. Boisvert FM, Lam YW, Lamont D, Lamond Al: A quantitative proteomics analysis of subcellular proteome localization and changes induced by DNA damage. Mol Cell Proteomics 2010, 9:457-470.

40. Moore HM, Bai BY, Boisvert FM, Latonen L, Rantanen V, Simpson JC, Pepperkok R, Lamond Al, Laiho M: Quantitative Proteomics and Dynamic Imaging of the Nucleolus Reveal Distinct Responses to UV and lonizing Radiation. Mol Cell Proteomics 2011, 10:15
41. Guerra-Rebollo M, Mateo F, Franke K, Huen MSY, Lopitz-Otsoa F, Rodriguez MS, Plans V, Thomson TM: Nucleolar exit of RNF8 and BRCA1 in response to DNA damage. Exp Cell Res 2012, 318:2365-2376.

42. Yuan X, Zhou Y, Casanova E, Chai M, Kiss E, Grone HJ, Schutz G, Grummt I: Genetic inactivation of the transcription factor TIF-IA leads to nucleolar disruption, cell cycle arrest, and p53-mediated apoptosis. Mol Cell 2005, 19:77-87.

43. Rubbi CP, Milner J: Disruption of the nucleolus mediates stabilization of p53 in response to DNA damage and other stresses. EMBO J 2003, 22:6068-6077.

44. Pestov DG, Strezoska Z, Lau LF: Evidence of p53-dependent cross-talk between ribosome biogenesis and the cell cycle: Effects of nucleolar protein bop1 on G(1)/S transition. Mol Cell Biol 2001, 21:4246-4255.

45. Olson MO: Sensing cellular stress: another new function for the nucleolus? SCi STKE 2004, 2004:pe10.

46. Zhang Y, Lu H: Signaling to $\mathrm{p} 53$ : ribosomal proteins find their way. Cancer Cell 2009, 16:369-377.

47. Deisenroth C, Zhang Y: Ribosome biogenesis surveillance: probing the ribosomal protein-Mdm2-p53 pathway. Oncogene 2010, 29:4253-4260.

48. Boulon S, Westman BJ, Hutten S, Boisvert FM, Lamond Al: The nucleolus under stress. Mol Cell 2010, 40:216-227.

49. de Marval PLM, Zhang YP: The RP-Mdm2-p53 Pathway and Tumorigenesis. Oncotarget 2011, 2:234-238.

50. Bursac S, Brdovcak MC, Donati G, Volarevic S: Activation of the tumor suppressor p53 upon impairment of ribosome biogenesis. Biochim Biophys Acta 1842, 2014:817-830.

51. Nemeth A, Langst $\mathrm{G}$ : Genome organization in and around the nucleolus. Trends Genet 2011, 27:149-156.

52. Guetg C, Santoro R: Formation of nuclear heterochromatin The nucleolar point of view. Epigenetics 2012, 7:811-814

53. Stults DM, Killen MW, Williamson EP, Hourigan JS, Vargas HD, Arnold SM Moscow JA, Pierce AJ: Human rRNA gene clusters are recombinational hotspots in cancer. Cancer Res 2009, 69:9096-9104.

54. Kobayashi T: Regulation of ribosomal RNA gene copy number and its role in modulating genome integrity and evolutionary adaptability in yeast. Cell Mol Life Sci 2011, 68:1395-1403.

55. Paredes S, Branco AT, Hartl DL, Maggert KA, Lemos B: Ribosomal DNA deletions modulate genome-wide gene expression: "rDNA-sensitive" genes and natural variation. PLoS Genet 2011, 7:e1001376.

56. Ide S, Miyazaki T, Maki H, Kobayashi T: Abundance of ribosomal RNA gene copies maintains genome integrity. Science 2010, 327:693-696.

57. Guetg C, Lienemann P, Sirri V, Grummt I, Hernandez-Verdun D, Hottiger MO, Fussenegger M, Santoro R: The NoRC complex mediates the heterochromatin formation and stability of silent rRNA genes and centromeric repeats. EMBO J 2010, 29:2135-2146.

58. Paredes S, Maggert KA: Ribosomal DNA contributes to global chromatin regulation. Proc Natl Acad Sci U S A 2009, 106:17829-17834.

59. Goodfellow SJ, Zomerdijk JC: Basic mechanisms in RNA polymerase I transcription of the ribosomal RNA genes. Subcell Biochem 2013, 61:211-236

60. Schneider DA: RNA polymerase I activity is regulated at multiple steps in the transcription cycle: recent insights into factors that influence transcription elongation. Gene 2012, 493:176-184.

61. Beckmann H, Chen JL, O'Brien T, Tjian R: Coactivator and promoter-selective properties of RNA polymerase I TAFs. Science 1995, 270:1506-1509.

62. Friedrich JK, Panov KI, Cabart P, Russell J, Zomerdijk JC: TBP-TAF complex SL1 directs RNA polymerase I pre-initiation complex formation and stabilizes upstream binding factor at the rDNA promoter. J Biol Chem 2005, 280:29551-29558.

63. Miller G, Panov KI, Friedrich JK, Trinkle-Mulcahy L, Lamond Al, Zomerdijk JC: hRRN3 is essential in the SL1-mediated recruitment of RNA Polymerase I to rRNA gene promoters. EMBO J 2001, 20:1373-1382.

64. Rudloff U, Eberhard D, Grummt I: The conserved core domain of the human TATA binding protein is sufficient to assemble the multisubunit RNA polymerase I-specific transcription factor SL1. Proc Natl Acad Sci U S A 1994, 91:8229-8233.

65. Putnam CD, Copenhaver GP, Denton ML, Pikaard CS: The RNA polymerase I transactivator upstream binding factor requires its dimerization domain and high-mobility-group (HMG) box 1 to bend, wrap, and positively supercoil enhancer DNA. Mol Cell Biol 1994, 14:6476-6488. 
66. Bazett-Jones DP, Leblanc B, Herfort M, Moss T: Short-range DNA looping by the Xenopus HMG-box transcription factor, xUBF. Science 1994, 264:1134-1137.

67. Stefanovsky VY, Pelletier G, Bazett-Jones DP, Crane-Robinson C, Moss T: DNA looping in the RNA polymerase I enhancesome is the result of non-cooperative in-phase bending by two UBF molecules. Nucleic Acids Res 2001, 29:3241-3247.

68. Bell SP, Learned RM, Jantzen HM, Tjian R: Functional cooperativity between transcription factors UBF1 and SL1 mediates human ribosomal RNA synthesis. Science 1988, 241:1192-1197.

69. Hempel WM, Cavanaugh AH, Hannan RD, Taylor L, Rothblum LI: The species-specific RNA polymerase I transcription factor SL-1 binds to upstream binding factor. Mol Cell Biol 1996, 16:557-563.

70. Zomerdijk JC, Beckmann H, Comai L, Tjian R: Assembly of transcriptionally active RNA polymerase I initiation factor SL1 from recombinant subunits. Science 1994, 266:2015-2018.

71. Heix J, Zomerdijk JC, Ravanpay A, Tjian R, Grummt I: Cloning of murine RNA polymerase I-specific TAF factors: conserved interactions between the subunits of the species-specific transcription initiation factor TIF-IB/ SL1. Proc Natl Acad Sci U S A 1997, 94:1733-1738.

72. Comai $\mathrm{L}$, Tanese $\mathrm{N}$, Tjian $\mathrm{R}$ : The TATA-binding protein and associated factors are integral components of the RNA polymerase I transcription factor, SL1. Cell 1992, 68:965-976.

73. O'Sullivan AC, Sullivan GJ, McStay B: UBF binding in vivo is not restricted to regulatory sequences within the vertebrate ribosomal DNA repeat. Mol Cell Biol 2002, 22:657-668.

74. Sanij E, Hannan RD: The role of UBF in regulating the structure and dynamics of transcriptionally active rDNA chromatin. Epigenetics 2009, 4:374-382.

75. Poortinga G, Wall M, Sanij E, Siwicki K, Ellul J, Brown D, Holloway TP, Hannan $\mathrm{RD}, \mathrm{McArthur} \mathrm{GA}$ : c-MYC coordinately regulates ribosomal gene chromatin remodeling and Pol I availability during granulocyte differentiation. Nucleic Acids Res 2011, 39:3267-3281

76. Panov KI, Friedrich JK, Russell J, Zomerdijk JC: UBF activates RNA polymerase I transcription by stimulating promoter escape. EMBO J 2006, 25:3310-3322.

77. Stefanovsky V, Langlois F, Gagnon-Kugler T, Rothblum LI, Moss T: Growth factor signaling regulates elongation of RNA polymerase I transcription in mammals via UBF phosphorylation and r-chromatin remodeling. Mol Cell 2006, 21:629-639.

78. Hamperl S, Wittner M, Babl V, Perez-Fernandez J, Tschochner H, Griesenbeck J: Chromatin states at ribosomal DNA loci. Biochim Biophys Acta 1829, 2013:405-417

79. Poortinga G, Quinn LM, Hannan RD: Targeting RNA polymerase I to treat MYC-driven cancer. Oncogene 2014, Epub ahead of print.

80. Sanij E, Poortinga G, Sharkey K, Hung S, Holloway TP, Quin J, Robb E, Wong LH, Thomas WG, Stefanovsky V, Moss T, Rothblum L, Hannan KM, McArthur GA, Pearson RB, Hannan RD: UBF levels determine the number of active ribosomal RNA genes in mammals. J Cell Biol 2008, 183:1259-1274.

81. Santoro R, Li J, Grummt I: The nucleolar remodeling complex NoRC mediates heterochromatin formation and silencing of ribosomal gene transcription. Nat Genet 2002, 32:393-396.

82. Strohner R, Nemeth A, Jansa P, Hofmann-Rohrer U, Santoro R, Langst G, Grummt I: NoRC-a novel member of mammalian ISWI-containing chromatin remodeling machines. EMBO J 2001, 20:4892-4900.

83. Grummt I, Langst G: Epigenetic control of RNA polymerase I transcription in mammalian cells. Biochim Biophys Acta 1829, 2013:393-404.

84. Heix J, Vente A, Voit R, Budde A, Michaelidis TM, Grummt I: Mitotic silencing of human rRNA synthesis: inactivation of the promoter selectivity factor SL1 by cdc2/cyclin B-mediated phosphorylation. EMBO J 1998, 17:7373-7381.

85. Sirri V, Roussel P, Hernandez-Verdun D: The mitotically phosphorylated form of the transcription termination factor TTF- 1 is associated with the repressed rDNA transcription machinery. J Cell Sci 1999, 112(Pt 19):3259-3268.

86. Voit R, Hoffmann M, Grummt I: Phosphorylation by G1-specific cdk-cyclin complexes activates the nucleolar transcription factor UBF. EMBO J 1999, 18:1891-1899.

87. Grummt I: Life on a planet of its own: regulation of RNA polymerase I transcription in the nucleolus. Genes Dev 2003, 17:1691-1702.

88. Roussel P, Andre C, Comai L, Hernandez-Verdun D: The rDNA transcription machinery is assembled during mitosis in active NORs and absent in inactive NORs. J Cell Biol 1996, 133:235-246.
89. Roussel P, Andre C, Masson C, Geraud G, Hernandez-Verdun D: Localization of the RNA polymerase I transcription factor hUBF during the cell cycle. J Cell Sci 1993, 104(Pt 2):327-337.

90. Prieto JL, McStay B: Nucleolar biogenesis: the first small steps. Biochem Soc Trans 2005, 33:1441-1443.

91. Prieto $\mathrm{J}$, McStay B: Recruitment of factors linking transcription and processing of pre-rRNA to NOR chromatin is UBF-dependent and occurs independent of transcription in human cells. Genes Dev 2007, 21:2041-2054

92. Grob A, Colleran C, McStay B: Construction of synthetic nucleoli in human cells reveals how a major functional nuclear domain is formed and propagated through cell division. Genes Dev 2014, 28:220-230.

93. Mais C, Wright JE, Prieto JL, Raggett SL, McStay B: UBF-binding site arrays form pseudo-NORs and sequester the RNA polymerase I transcription machinery. Genes Dev 2005, 19:50-64.

94. Trumtel S, Leger-Silvestre I, Gleizes PE, Teulieres F, Gas N: Assembly and functional organization of the nucleolus: ultrastructural analysis of Saccharomyces cerevisiae mutants. Mol Biol Cell 2000, 11:2175-2189.

95. Hernandez-Verdun D, Roussel P, Thiry M, Sirri V, Lafontaine DLJ: The nucleolus: structure/function relationship in RNA metabolism. Wiley Interdisciplinary Reviews-RNA 2010, 1:415-431.

96. Koberna K, Malinsky J, Pliss A, Masata M, Vecerova J, Fialova M, Bednar J, Raska I: Ribosomal genes in focus: new transcripts label the dense fibrillar components and form clusters indicative of "Christmas trees" in situ. J Cell Biol 2002, 157:743-748.

97. Tschochner $\mathrm{H}$, Hurt E: Pre-ribosomes on the road from the nucleolus to the cytoplasm. Trends Cell Biol 2003, 13:255-263.

98. Boisvert FM, Lamond Al: p53-Dependent subcellular proteome localization following DNA damage. Proteomics 2010, 10:4087-4097.

99. Kar B, Liu BH, Zhou ZJ, Lam YW: Quantitative nucleolar proteomics reveals nuclear re-organization during stress- induced senescence in mouse fibroblast. BMC Cell Biol 2011, 12:13.

100. Leung AKL, Gerlich D, Miller G, Lyon C, Lam YW, Lleres D, Daigle N, Zomerdijk J, Ellenherg J, Lamond Al: Quantitative kinetic analysis of nucleolar breakdown and reassembly during mitosis in live human cells. J Cell Biol 2004, 166:787-800.

101. Emmott E, Rodgers MA, Macdonald A, McCrory S, Ajuh P, Hiscox JA: Quantitative proteomics using stable isotope labeling with amino acids in cell culture reveals changes in the cytoplasmic, nuclear, and nucleolar proteomes in Vero cells infected with the coronavirus infectious bronchitis virus. Mol Cell Proteomics 2010, 9:1920-1936.

102. Lam YW, Evans VC, Heesom KJ, Lamond Al, Matthews DA: Proteomics analysis of the nucleolus in adenovirus-infected cells. Mol Cell Proteomics 2010, 9:117-130.

103. Olson MO, Dundr M, Szebeni A: The nucleolus: an old factory with unexpected capabilities. Trends Cell Biol 2000, 10:189-196.

104. Donati G, Montanaro L, Derenzini M: Ribosome Biogenesis and Control of Cell Proliferation: p53 Is Not Alone. Cancer Res 2012, 72:1602-1607.

105. Tsai RYL, Pederson T: Connecting the nucleolus to the cell cycle and human disease. FASEB J 2009, 6:771-776.

106. Jacob MD, Audas TE, Uniacke J, Trinkle-Mulcahy L, Lee S: Environmental Cues Induce a Long Noncoding RNA-dependent Remodeling of the Nucleolus. Mol Biol Cell 2013, 18:2943-2953.

107. Audas TE, Jacob MD, Lee S: The nucleolar detention pathway: A cellular strategy for regulating molecular networks. Cell Cycle 2012, 11:2059-2062.

108. Emmott E, Hiscox JA: Nucleolar targeting: the hub of the matter. EMBO Rep 2009, 10:231-238.

109. Grummt I, Voit R: Linking rDNA transcription to the cellular energy supply. Cell Cycle 2010, 9:225-226.

110. Mayer C, Grummt I: Cellular stress and nucleolar function. Cell Cycle 2005, 4:1036-1038.

111. Chedin S, Laferte A, Hoang T, Lafontaine DLJ, Riva M, Carles C: Is ribosome synthesis controlled by Pol I transcription? Cell Cycle 2007, 6:11-15.

112. Murayama A, Ohmori K, Fujimura A, Minami H, Yasuzawa-Tanaka K, Kuroda T, Oie S, Daitoku H, Okuwaki M, Nagata K, Fukamizu A, Kimura K, Shimizu T, Yanagisawa J: Epigenetic control of rDNA loci in response to intracellular energy status. Cell 2008, 133:627-639.

113. Grummt I: Wisely chosen paths - regulation of rRNA synthesis. FEBS J 2010, 277:4626-4639.

114. Grummt I, Ladurner AG: A metabolic throttle regulates the epigenetic state of rDNA. Cell 2008, 133:577-580 
115. Burger K, Eick D: Functional ribosome biogenesis is a prerequisite for p53 destabilization: impact of chemotherapy on nucleolar functions and RNA metabolism. Biol Chem 2013, 9:1133-1143.

116. Ruggero D, Pandolfi PP: Does the ribosome translate cancer? Nat Rev Cancer 2003, 3:179-192.

117. Shcherbik N, Pestov DG: Ubiquitin and ubiquitin-like proteins in the nucleolus: multitasking tools for a ribosome factory. Genes Cancer 2010, 1:681-689.

118. Hannan RD, Drygin D, Pearson RB: Targeting RNA polymerase I transcription and the nucleolus for cancer therapy. Expert Opin Ther Targets 2013, 8:873-878.

119. Nemeth A, Perez-Fernandez J, Merkl P, Hamperl S, Gerber J, Griesenbeck J, Tschochner $\mathrm{H}$ : RNA polymerase I termination: Where is the end? Biochimica et Biophysica Acta (BBA) - Gene Regulatory Mechanisms 2013, 1829:306-317.

120. Sloan KE, Bohnsack MT, Watkins NJ: The 5 S RNP couples p53 homeostasis to ribosome biogenesis and nucleolar stress. Cell Reports 2013, 5:237-247.

121. Horn HF, Vousden $\mathrm{KH}$ : Cooperation between the ribosomal proteins L5 and L11 in the p53 pathway. Oncogene 2008, 27:5774-5784.

122. Lohrum MAE, Ludwig RL, Kubbutat MHG, Hanlon M, Vousden $\mathrm{KH}$ : Regulation of HDM2 activity by the ribosomal protein L11. Cancer Cell 2003, 3:577-587

123. Bhat KP, Itahana K, Jin AW, Zhang YP: Essential role of ribosomal protein L11 in mediating growth inhibition-induced p53 activation. EMBO J 2004, 23:2402-2412.

124. Dai MS, Lu H: Inhibition of MDM2-mediated p53 ubiquitination and degradation by ribosomal protein L5. J Biol Chem 2004, 279:44475-44482.

125. Dai MS, Shi DD, Jin YT, Sun XX, Zhang YP, Grossman SR, Lu H: Regulation of the MDM2-p53 pathway by ribosomal protein L11 involves a post-ubiquitination mechanism. J Biol Chem 2006, 281:24304-24313.

126. Bursac S, Brdovcak MC, Pfannkuchen M, Orsolic I, Golomb L, Zhu Y, Katz C, Daftuar L, Grabusic K, Vukelic I, Filić V, Oren M, Prives C, Volarevic S: Mutual protection of ribosomal proteins L5 and L11 from degradation is essential for p53 activation upon ribosomal biogenesis stress. Proc Natl Acad Sci U S A 2012, 109:20467-20472.

127. Fumagalli S, Ivanenkov W, Teng T, Thomas G: Suprainduction of p53 by disruption of $40 \mathrm{~S}$ and $60 \mathrm{~S}$ ribosome biogenesis leads to the activation of a novel G2/M checkpoint. Genes Dev 2012, 26:1028-1040.

128. Macias E, Jin AW, Deisenroth C, Bhat K, Mao H, Lindstrom MS, Zhang YP: An ARF-Independent c-MYC-Activated Tumor Suppression Pathway Mediated by Ribosomal Protein-Mdm2 Interaction. Cancer Cell 2010, 18:231-243.

129. Zhang YP, Wolf GW, Bhat K, Jin A, Allio T, Burkhart WA, Xiong Y: Ribosomal protein $\mathrm{L} 11$ negatively regulates oncoprotein MDM2 and mediates a p53-dependent ribosomal-stress checkpoint pathway. Mol Cell Biol 2003 23:8902-8912.

130. Ma H, Pederson T: The Nucleolus Stress Response is Coupled to an ATRChk1-Mediated G2 Arrest. Mol Biol Cell 2013, 9:1334-1342.

131. Holmberg Olausson K, Nister M, Lindstrom MS: p53 -Dependent and -Independent Nucleolar Stress Responses. Cells 2012, 1:774-798.

132. Sutherland H, Bickmore WA: Transcription factories: gene expression in unions? Nat Rev Genet 2009, 10:457-466.

133. Misteli T: Concepts in nuclear architecture. Bioessays 2005, 27:477-487.

134. Misteli T: Spatial positioning; a new dimension in genome function. Cell 2004, 119:153-156.

135. Chubb JR, Boyle S, Perry P, Bickmore WA: Chromatin motion is constrained by association with nuclear compartments in human cells. Curr Biol 2002, 12:439-445.

136. Manuelidis L: Different central nervous system cell types display distinct and nonrandom arrangements of satellite DNA sequences. Proc Natl Acad Sci U S A 1984, 81:3123-3127.

137. Akhmanova A, Verkerk T, Langeveld A, Grosveld F, Galjart N: Characterisation of transcriptionally active and inactive chromatin domains in neurons. J Cell Sci 2000, 113(Pt 24):4463-4474.

138. Stahl A, Hartung M, Vagnercapodano AM, Fouet C: Chromosomal constitution of nucleolus-associated chromatin in man. Hum Genet 1976, 35:27-34.

139. Nemeth A, Conesa A, Santoyo-Lopez J, Medina I, Montaner D, Peterfia B, Solovei I, Cremer T, Dopazo J, Langst G: Initial Genomics of the Human Nucleolus. PLoS Genet 2010, 6:11.

140. Floutsakou I, Agrawal S, Nguyen TT, Seoighe C, Ganley AR, McStay B: The shared genomic architecture of human nucleolar organizer regions. Genome Res 2013, 23:2003-2012.
141. van Koningsbruggen $S$, Gierlinski M, Schofield P, Martin D, Barton GJ, Ariyurek Y, den Dunnen JT, Lamond Al: High-resolution whole-genome sequencing reveals that specific chromatin domains from most human chromosomes associate with nucleoli. Mol Biol Cell 2010, 21:3735-3748.

142. Zhang LF, Huynh KD, Lee JT: Perinucleolar targeting of the inactive $X$ during $S$ phase: evidence for a role in the maintenance of silencing Cell 2007, 129:693-706

143. Fedoriw AM, Starmer J, Yee D, Magnuson T: Nucleolar association and transcriptional inhibition through 5S rDNA in mammals. PLOS Genet 2012, 8:e1002468.

144. Thompson M, Haeusler RA, Good PD, Engelke DR: Nucleolar clustering of dispersed tRNA genes. Science 2003, 302:1399-1401.

145. Haeusler RA, Engelke DR: Spatial organization of transcription by RNA polymerase III. Nucleic Acids Res 2006, 34:4826-4836.

146. Ong CT, Corces VG: CTCF: an architectural protein bridging genome topology and function. Nat Rev Genet 2014, 15:234-246.

147. Yusufzai TM, Tagami H, Nakatani Y, Felsenfeld G: CTCF tethers an insulator to subnuclear sites, suggesting shared insulator mechanisms across species. Mol Cell 2004, 13:291-298.

148. van de Nobelen S, Rosa-Garrido M, Leers J, Heath H, Soochit W, Joosen L, Jonkers I, Demmers J, van der Reijden M, Torrano V, Grosveld F, Delgado MD, Renkawitz R, Galjart N, Sleutels F: CTCF regulates the local epigenetic state of ribosomal DNA repeats. Epigenetics Chromatin 2010, 3:19-40.

149. Pandey RR, Mondal T, Mohammad F, Enroth S, Redrup L, Komorowski J, Nagano T, Mancini-DiNardo D, Kanduri C: Kcnq1ot1 Antisense Noncoding RNA Mediates Lineage-Specific Transcriptional Silencing through Chromatin-Level Regulation. Mol Cell 2008, 32:232-246.

150. Mohammad F, Pandey RR, Nagano T, Chakalova L, Mondal T, Fraser P, Kanduri C: Kcnq1ot1/Lit1 noncoding RNA mediates transcriptional silencing by targeting to the perinucleolar region. Mol Cell Biol 2008 28:3713-3728

151. Eickbush TH, Eickbush DG: Finely orchestrated movements: evolution of the ribosomal RNA genes. Genetics 2007, 175:477-485

152. Kobayashi T: Strategies to maintain the stability of the ribosomal RNA gene repeats-collaboration of recombination, cohesion, and condensation. Genes Genet Syst 2006, 81:155-161.

153. Grewal SIS, Jia ST: Heterochromatin revisited. Nat Rev Genet 2007, 8:35-46

154. Killen MW, Stults DM, Adachi N, Hanakahi L, Pierce AJ: Loss of Bloom syndrome protein destabilizes human gene cluster architecture. Hum Mol Genet 2009, 18:3417-3428.

155. MacLeod RA, Spitzer D, Bar-Am I, Sylvester JE, Kaufmann M, Wernich A, Drexler HG: Karyotypic dissection of Hodgkin's disease cell lines reveals ectopic subtelomeres and ribosomal DNA at sites of multiple jumping translocations and genomic amplification. Leukemia 2000, 14:1803-1814.

156. Hallgren J, Pietrzak M, Rempala G, Nelson PT, Hetman M: Neurodegeneration-associated instability of ribosomal DNA. Biochim Biophys Acta 1842, 2014:860-868.

157. Pietrzak M, Rempala G, Nelson PT, Zheng JJ, Hetman M: Epigenetic silencing of nucleolar rRNA genes in Alzheimer's disease. PLoS One 2011, 6:e22585.

158. Kobayashi T: How does genome instability affect lifespan? Genes Cells 2011, 16:617-624.

159. Kobayashi T, Heck DJ, Nomura M, Horiuchi T: Expansion and contraction of ribosomal DNA repeats in Saccharomyces cerevisiae: requirement of replication fork blocking (Fob1) protein and the role of RNA polymerase I. Genes Dev 1998, 12:3821-3830.

160. Tsang E, Carr AM: Replication fork arrest, recombination and the maintenance of ribosomal DNA stability. DNA Repair 2008, 7:1613-1623.

161. Torres-Rosell J, Sunjevaric I, De Piccoli G, Sacher M, Eckert-Boulet N, Reid R, Jentsch S, Rothstein R, Aragon L, Lisby M: The Smc5-Smc6 complex and SUMO modification of Rad52 regulates recombinational repair at the ribosomal gene locus. Nat Cell Biol 2007, 9:923-931.

162. Kobayashi T: A new role of the rDNA and nucleolus in the nucleus-rDNA instability maintains genome integrity. Bioessays 2008, 30:267-272.

163. Ganley AR, Kobayashi T: Ribosomal DNA and cellular senescence: new evidence supporting the connection between rDNA and aging. FEMS Yeast Res 2013, Epub ahead of print.

164. French SL, Osheim YN, Cioci F, Nomura M, Beyer AL: In exponentially growing Saccharomyces cerevisiae cells, rRNA synthesis is determined by the summed RNA polymerase I loading rate rather than by the number of active genes. Mol Cell Biol 2003, 23:1558-1568. 
165. Clemente-Blanco A, Mayan-Santos M, Schneider DA, Machin F, Jarmuz A, Tschochner H, Aragon L: Cdc14 inhibits transcription by RNA polymerase I during anaphase. Nature 2009, 458:219-222.

166. Freeman L, Aragon-Alcaide L, Strunnikov A: The condensin complex governs chromosome condensation and mitotic transmission of rDNA. J Cell Biol 2000, 149:811-824.

167. Huang J, Brito IL, Villen J, Gygi SP, Amon A, Moazed D: Inhibition of homologous recombination by a cohesin-associated clamp complex recruited to the rDNA recombination enhancer. Genes Dev 2006, 20:2887-2901

168. Lavoie $B D$, Hogan $E$, Koshland D: In vivo requirements for rDNA chromosome condensation reveal two cell-cycle-regulated pathways for mitotic chromosome folding. Genes Dev 2004, 18:76-87.

169. Hariharan N, Sussman MA: Stressing on the nucleolus in cardiovascular disease. Biochim Biophys Acta 1842, 2014:798-801.

170. Ruggero D: Revisiting the Nucleolus: From Marker to Dynamic Integrator of Cancer Signaling. Sci Signal 2012, 5:pe38.

171. Bywater MJ, Pearson RB, McArthur GA, Hannan RD: Dysregulation of the basal RNA polymerase transcription apparatus in cancer. Nat Rev Cancer 2013, 13:299-314.

172. Derenzini M, Trere D, Pession A, Govoni M, Sirri V, Chieco P: Nucleolar size indicates the rapidity of cell proliferation in cancer tissues. J Pathol 2000, 191:181-186.

173. Derenzini M, Montanaro L, Trere D: What the nucleolus says to a tumour pathologist. Histopathology 2009, 54:753-762.

174. Bywater MJ, Poortinga G, Sanij E, Hein N, Peck A, Cullinane C, Wall M, Cluse L, Drygin D, Anderes K, Huser N, Proffitt C, Bliesath J, Haddach M, Schwaebe MK, Ryckman DM, Rice WG, Schmitt C, Lowe SW, Johnstone RW, Pearson RB, McArthur GA, Hannan RD: Inhibition of RNA polymerase I as a therapeutic strategy to promote cancer-specific activation of p53. Cancer Cell 2012, 22:51-65.

175. Peltonen $\mathrm{K}$, Colis L, Liu H, Trivedi R, Moubarek MS, Moore HM, Bai B, Rudek MA, Bieberich CJ, Laiho M: A targeting modality for destruction of RNA polymerase I that possesses anticancer activity. Cancer Cell 2014, 25:77-90.

176. Narla A, Ebert BL: Ribosomopathies: human disorders of ribosome dysfunction. Blood 2010, 115:3196-3205.

177. Bose T, Lee KK, Lu S, Xu B, Harris B, Slaughter B, Unruh J, Garrett A, McDowell W, Box A, Li H, Peak A, Ramachandran S, Seidel C, Gerton JL: Cohesin proteins promote ribosomal RNA production and protein translation in yeast and human cells. PLOS Genet 2012, 8:e1002749.

178. Harris B, Bose T, Lee KK, Wang F, Lu S, Ross RT, Zhang Y, French SL, Beyer AL, Slaughter BD, Unruh JR, Gerton JL: Cohesion promotes nucleolar structure and function. Mol Biol Cell 2014, 25:337-346.

179. Zhang Q, Shalaby NA, Buszczak M: Changes in rRNA transcription influence proliferation and cell fate within a stem cell lineage. Science 2014, 343:298-301.

180. Hayashi $Y$, Kuroda T, Kishimoto H, Wang C, Iwama A, Kimura K: Downregulation of rRNA Transcription Triggers Cell Differentiation. PLoS One 2014, 9:e98586

181. Garcia Moreno LM, Cimadevilla JM, Gonzalez Pardo H, Zahonero MC, Arias $J$ : NOR activity in hippocampal areas during the postnatal development and ageing. Mech Ageing Dev 1997, 97:173-181.

182. Parlato R, Kreiner G: Nucleolar activity in neurodegenerative diseases: a missing piece of the puzzle? J Mol Med 2013, 91:541-547.

183. Lee J, Hwang YJ, Boo JH, Han D, Kwon OK, Todorova K, Kowall NW, Kim Y, Ryu $\mathrm{H}$ : Dysregulation of upstream binding factor-1 acetylation at K352 is linked to impaired ribosomal DNA transcription in Huntington's disease. Cell Death Differ 2011, 18:1726-1735.

184. Tsoi H, Chan HY: Roles of the nucleolus in the CAG RNA-mediated toxicity. Biochim Biophys Acta 1842, 2014:779-784

185. Rieker C, Engblom D, Kreiner G, Domanskyi A, Schober A, Stotz S, Neumann M, Yuan X, Grummt I, Schutz G, Parlato R: Nucleolar disruption in dopaminergic neurons leads to oxidative damage and parkinsonism through repression of mammalian target of rapamycin signaling. J Neurosci 2011, 31:453-460.

186. Baltanas FC, Casafont I, Weruaga E, Alonso JR, Berciano MT, Lafarga M: Nucleolar disruption and cajal body disassembly are nuclear hallmarks of DNA damage-induced neurodegeneration in purkinje cells. Brain Pathol 2011, 21:374-388.

doi:10.1186/2045-3701-4-43

Cite this article as: Diesch et al:: Perturbations at the ribosomal genes loci are at the centre of cellular dysfunction and human disease. Cell \& Bioscience 2014 4:43.

\section{Submit your next manuscript to BioMed Central and take full advantage of:}

- Convenient online submission

- Thorough peer review

- No space constraints or color figure charges

- Immediate publication on acceptance

- Inclusion in PubMed, CAS, Scopus and Google Scholar

- Research which is freely available for redistribution

Submit your manuscript at www.biomedcentral.com/submit
C Biomed Central 